\title{
Exergy Cost Analysis of New Method for Efficiency Improvement in Small Gas Turbines Using LNG Cold Exergy
}

\author{
Mojtaba. Babaelahi', Hamed. Jafari, Farnaz. Amini. Hajibashi \\ Department of Mechanical Engineering, University of Qom, Qom, Iran, P.O. Box 3716146611. \\ "E-mail: mbabaelahi@gmail.com, m.babaelahi@qom.ac.ir
}

Received 05 September 2018, Revised 12 October 2018, Accepted 21 October 2018

\begin{abstract}
The gas turbine systems are some equipment; that have extensive industrial and military applications due to their unique characteristics. One of the major problems in association with utilization of gas turbines is the output power and thermal efficiency. One of the major methods that are used for increasing the power and thermal efficiency in this type of power systems is compressor's inlet air cooling. In this paper, the effect of fuel replacement for methane gasfired gas turbines with LNG and cooling the compressor's air inlet with the cold exergy of LNG fuel evaporation will be examined. In the first step, the energy balance equation is applied to the gas turbine with Methane and LNG fuel separately. Then the problem of fuel replacement in some mini and micro gas turbine has been examined and the appropriate engine with the most power and thermal efficiency is selected. In the next step, the exergetic analysis of considered systems is performed and exergetic parameters of the two systems are compared together. Finally, the advance exergy analysis is performed and effects of fuel replacement on exergetic cost parameter and environmental characteristics are evaluated.
\end{abstract}

Keywords: Gas turbine; LNG; cooling; power; efficiency; exergy cost.

\section{Introduction}

Gas turbines are the subset of power generation systems that have many major applications due to their specific capabilities from low power range to high power. One of the problems related to gas turbines is the low thermal efficiency in these kinds of turbines. Thus, many extensive types of research to increase the thermal efficiency of these turbines have been performed. The methods that used for thermal efficiency increment can be divided into three different categories.

a) Cooling the compressor air inlet

b) Heat recovery from exhaust

c) Using energy storage

The most proposed methods in the second and third categories required the change in the gas turbine cycle, combustion mechanism, design parameters and thermodynamic conditions of the cycle. Therefore, the use of these methods is only possible for companies that have access to turbine design specifications. In this section, all of the methods used for improvement in the gas turbine engine are reviewed.

Foster [1] proposed a method and apparatus for increasing output power and the thermal efficiency of a gas turbine power plant. In this research, the inlet air is superchilled before it enters the compressor. Enhancing gas turbine performance by intake air cooling using an absorption chiller was studied by Mohanty and Paloso Jr [2]. Authors found that air temperature reduction from the ambient condition to $15^{\circ} \mathrm{C}$ increase the instantaneous output power between 8 to $13 \%$ and $11 \%$ additional electricity could be generated from the same gas turbine power plant. De Lucia et al. [3] investigated the benefit of compressor inlet air cooling for gas turbine cogeneration plants with the comparative analysis of different cooling methods. These analyses have performed for the LM6000 gas turbine in a cogeneration plant operated in base load. In this research, the absorption and evaporative air cooling systems are considered and their performance and economic benefits compared for the dry low-NOx LM6000 version. Najjar [4] compared the effects an inlet air pre-cooler on performance enhancement of gas turbine engines. In this paper, the cooling system is connected to the evaporator of an ammonia absorption chiller that is driven by the heat recovered from the engine exhaust gases. Palsson et al. [5] studied the combined solid oxide fuel cell and gas turbine systems for efficient power and heat generation. In this paper, the performance of the gas turbine system and the effect of operational parameters are evaluated. Results show that the pressure ratio has an effective impact on the performance and the electrical efficiencies of more than $65 \%$ are possible at low-pressure ratios. The effects of the evaporative air inlet and outlet cooling on the recuperated gas turbine cycle were analyzed by Bassily [6]. Four different layouts of the recuperated gas turbine cycle were presented. The results showed that evaporative cooling of the inlet air could boost the efficiency up to $3.2 \%$ and the evaporative outlet cooling could increase the power up to $110 \%$ and cycle efficiency up to $16 \%$. Integration of steam injection and inlet air cooling for a gas turbine system was investigated by Wanga and Chiou [7]. In this study, the computer code was developed to simulate a Taipower's Frame 7B simple cycle gas turbine generator sets. Under the condition of local summer weather, the benefits obtained from the system implementing both steam injection gas turbine and inlet air cooling system 
features are more than a $70 \%$ in power and $20.4 \%$ improvement in heat rate. A comparison between two different types of air coolers, namely water spraying system, and the cooling coil system was carried out by Alhazmya and Najjar [8]. Yang et al. [9] conducted an analytical method for evaluation of the inlet air cooling for gas-steam combined cycle power plant with absorption chiller and saturated evaporative cooler. It was shown that inlet fogging is superior in power efficiency at $\mathrm{Ta} 15-20^{\circ} \mathrm{C}$ though it gains a smaller profit margin than inlet chilling. GTCC inlet chilling with absorption chiller is preferable in the zones with $\mathrm{Ta}>$ $25^{\circ} \mathrm{C}$ and $\mathrm{RH}>0.4$. Farzaneh-Gord et al. [10] carried out a comparison between two commons and one novel inlet air cooling method using turbo-expanders to improve the performance of a gas turbine located at the Khangiran refinery in Iran. Olivenza et al. [11] presented the new analytical model for a hybrid solar driven gas-turbine plant. The model validation by comparing with real prototype plants is very satisfactory. Dabwan and et al. [12] analysis the new integrated solar gas turbine cogeneration plant (ISGCPP). In this paper, results show that optimal integration of LFR with gas turbine cogeneration system can reduce $\mathrm{CO} 2$ emission by $18 \%$. The new combined-cycle of gas turbine and Stirling engine is proposed for power generation by Entezari et al [13]. In this paper, the exergoeconomic optimization is performed on the gas turbine cycle as well as combined-cycle. Genetic algorithm and TOPSIS method implemented to find the optimal operating point. Santos and et al. [14] modeled Brayton hybrid thermo-solar plants and considered Multi-stage recuperative configurations and different working fluids. Results show the good improvement over a reference plant.

In this paper, the effect of using LNG as the fuel in gas turbines and using its cold exergy to cool the compressor's inlet air is investigated. First, the energy balance rules are applied to each component and the operational parameters are evaluated. Then the effect of the selected cooling method on gas turbine systems efficiency is performed. For this object, gas turbines with different capacities $(30-2000 \mathrm{KW})$ have been examined and finally, suitable capacity for the suggested cooling procedure is chosen. After choosing suitable power, the effect of different parameters on the power and efficiency of the gas turbine is examined. To accurate evaluation of the proposed method, the advanced exergy cost analysis is examined and exergy cost factors and environmental impacts of the proposed system are evaluated.

\section{Thermal Simulation}

A schematic view of the gas turbine cycle with methane and LNG fuel is shown in Figures 1. The LNG contains 90.28 percent methane, 6.33 percent ethane, 2.49 percent propane, 0.49 percent butane, and 0.41 percent nitrogen. In the gas turbine cycle with LNG fuel, first, the available LNG in the tank enters to the LNG vaporizer then in the warming up process, heat is transferred from the air at compressor inlet to LNG and the LNG converted to steam. The LNG vaporizer is uncomplicated heat exchanger which vaporizes liquefied gas by using heat absorbed from the ambient air. In this heat exchanger, the LNG passes through a number of interconnected tubes in various series and parallel paths. Initially, energy analysis accordance with the first thermodynamic law is carried out to investigate the effects of replacement methane fuel with LNG and use cold exergy from LNG evaporation, and according to specified parameters and exergy analysis, the amount of inefficiency in the various components of the cycle is determined.

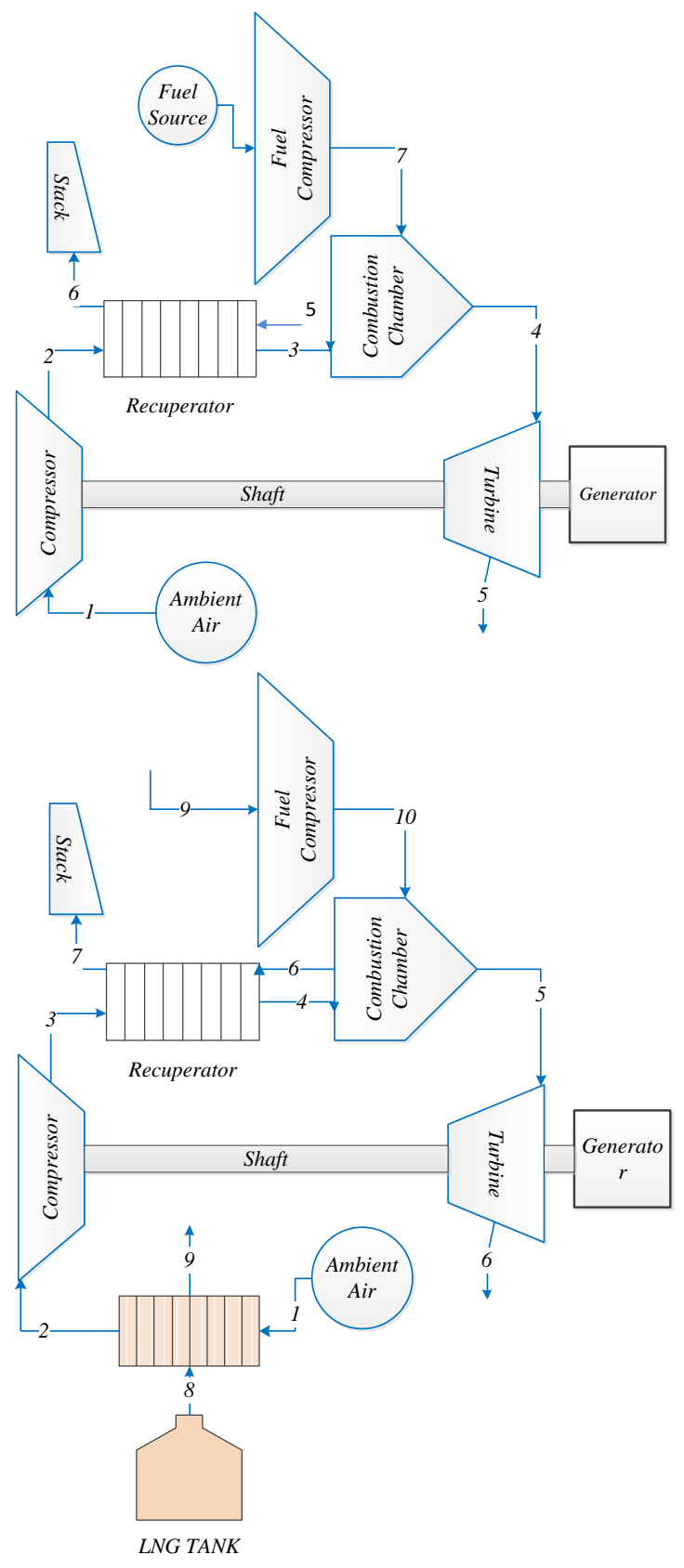

Figure 1. Schematic of gas turbine cycle with methane (CH4) and $L N G$ fuel.

\subsection{Energy analysis}

To simulate the gas turbine system, the energy balance equation in steady state conditions for each component is applied:

$$
\sum_{\text {in }} \dot{m}_{\text {in }} h_{\text {in }}-\sum_{\text {out }} \dot{m}_{\text {out }} h_{\text {out }}-\dot{W}+\dot{Q}=0
$$

Energy balance equations for each component based on the above equation and decision and input variables is evaluated and are mentioned in Appendix A.

\subsection{Exergy analysis}

The exergy equation for a selected control volume is generally expressed as below [15]: 


$$
\begin{aligned}
\sum \dot{Q}\left(1-\frac{T_{0}}{T}\right)-\dot{W} & \\
& +\sum_{\text {in }} \dot{m}_{\text {in }} e_{\text {in }} \\
& -\sum_{\text {out }}^{\dot{m}_{\text {out }} e_{\text {out }}=\dot{E}_{D}}
\end{aligned}
$$

Assuming the adiabatic behavior for all equipment, the term $\dot{E}_{Q}\left(\dot{Q}\left(1-T_{0} / T\right)\right)$ is ignored in the exergy equations in steady state conditions. $\dot{E}_{D}$ is the exergy destruction of the irreversible system. The specific exergy value for each input or output flow is determined from the following equation [15]:

$$
e=e_{p h}+e_{k}+e_{p}+e_{c h}
$$

where $e_{p h}, e_{k}, e_{p}$ and $e_{c h}$, are physical, kinetic, potential and chemical exergy respectively.

In this study, the amount of kinetic and potential exergy has not been considered and the chemical exergy is calculated based on exergy table. So special exergy in each case is equal to total physical and chemical exergy that is calculated from the equation (4).

$$
\begin{aligned}
e=e_{p h}+e_{c h}= & {\left[\left(h-h_{0}\right)-T_{0}\left(s-s_{0}\right)\right] } \\
& +\left[\sum x_{k} \bar{e}_{C H, k}\right. \\
& \left.+\bar{R} T_{0} \sum x_{k} \ln x_{k}\right]
\end{aligned}
$$

where, $\mathrm{s}$ and $\mathrm{h}$ are specific entropy and specific enthalpy, $T_{0}$ is the ISO temperature, $s_{0}$, and $h_{0}$ are entropy and enthalpy in $T_{0}$ and $\mathrm{P}_{0}, \bar{R}$ is gas constant and $\mathrm{x}_{\mathrm{k}}$ is the molar fraction of each element in the mixture (reference point ISO condition: $T_{0}=15^{0 c}$ and $\mathrm{P}_{0}=1.013$ bar).

\subsection{Exergy cost analysis}

Exergy cost of a flow is the number of exergy sources that consumed by the system for producing the flow. There are various applications that not only the exergy content is the critical parameter, but the required exergy for flow production is important. If the required resources are calculated in terms of exergy, the embodied exergy can be evaluated. The detail of this concept so-called exergy cost analysis is presented in [16] and in this section, the basic concept of this method is presented.

The exergy cost $\left(E x_{i}^{*}\right)$ of specific flow $\left(e_{i}\right)$ is the amount of exergy needed to produce this flow. Based on this definition, the unit exergy cost of a flow is the exergy cost per unit $\operatorname{exergy~} c_{i}=E x_{i}^{*} /_{E x_{i}}$. The exergy cost of a flow can be with a set of interrelated cost values:

The exergy cost is a conservative property and, therefore, the cost of the inlets is equal to that of the outlets $\left(A \cdot E x^{*}=0\right)$

In the absence of external assessment, the exergy cost of each flow entering the plant is equal to its exergy $\left(E x_{i}^{*}=E x_{i}\right)$

- If a fuel stream of a component has an output flow (nonexhausted fuel), its unit exergy cost is equal to input flow of this fuel stream.

If the product stream of a component has several outputs flows, all of the flows have the same unit exergy cost.

The production of component $(i)$ is used as fuel of other components or as a part of the total production of the plant:

$$
P_{i}=E x_{i 0}+\sum_{j=1}^{n} E x_{i j}, \quad i=0,1, \ldots, n
$$

In the above expression, if the component 0 is considered as the system environment and $j$ present the other component. The resources consumed by component $(i)$ can be written as:

$$
F_{i}=E x_{0 i}+\sum_{j=1}^{n} E x_{j i}, \quad i=0,1, \ldots, n
$$

In accordance with the proposed model, the cost of the resources and product in component $(i)$ can be calculated with Eq. (7) and (8):

$$
\begin{aligned}
& C_{F, i}=E x_{i 0}^{*}+\sum_{j=1}^{n} E x_{i j}^{*} \\
& C_{P, i}=E x_{0 i}^{*}+\sum_{j=1}^{n} E x_{i j}^{*}
\end{aligned}
$$

The unit exergy consumption $(k)$ is defined as the ratio of unit exergy cost of the product to unit exergy cost of fuel. Thus the component with minimum $k$ defines as the ideal component in each system.

Table 1. The operational parameters of selected gas turbines.

\begin{tabular}{|lcccccc|} 
Manufacturer & $\begin{array}{c}\text { Engine's } \\
\text { name }\end{array}$ & $\begin{array}{c}\text { Output Power } \\
(\mathrm{KW})\end{array}$ & $\begin{array}{c}\text { rotational speed } \\
(\mathrm{RPM})\end{array}$ & $\begin{array}{c}\text { Pressure } \\
\text { ratio }\end{array}$ & $\begin{array}{c}\text { Stack mass flow rate } \\
(\mathrm{kg} / \mathrm{s})\end{array}$ & $\begin{array}{c}\text { Stack temperature } \\
\left({ }^{\circ} \boldsymbol{C}\right)\end{array}$ \\
\hline Capstone & $\mathrm{C} 30$ & 30 & 96000 & 4 & 0.31 & $275^{\circ} \mathrm{C}$ \\
\hline Capstone & $\mathrm{C} 200$ & 200 & 61000 & 4 & 6.3 & $280^{\circ} \mathrm{C}$ \\
\hline Capstone & $\mathrm{C} 1000$ & 1000 & 61000 & 6.7 & 8.9 & $570^{\circ} \mathrm{C}$ \\
\hline OPRA & OP16 & $1.88 \times 10^{3}$ & 26000 & 6.7 \\
\hline
\end{tabular}


Table 2. Comparison between power and efficiency of different gas turbines (methane and LNG) in ISO conditions.

\begin{tabular}{|l|c|c|c|c|c|c|}
\hline \multirow{2}{*}{$\begin{array}{c}\text { Company's name } \\
\text { and engine's } \\
\text { name }\end{array}$} & \multicolumn{3}{|c|}{ Output power (KW) } & \multicolumn{3}{c|}{ Thermal efficiency } \\
\cline { 2 - 7 } & CH4 & LNG & $\begin{array}{c}\text { Improvement } \\
(\%)\end{array}$ & CH4 & LNG & $\begin{array}{c}\text { Improvement } \\
(\%)\end{array}$ \\
\hline C30 & 30 & 31.23 & 4.1 & 24.35 & 24.71 & 1.4784 \\
\hline C200 & 200 & 206.2 & 3.1 & 33.42 & 33.54 & 0.359 \\
\hline C1000 & 1000 & 1031.8 & 3.18 & 32.95 & 33.1 & 0.4552 \\
\hline OPRA & 1933.3 & 2041.1 & 5.5759 & 24.71 & 25.36 & 2.6305 \\
\hline
\end{tabular}

\section{Results and Discussion}

Based on the thermodynamic analysis, the various energy and exergy parameters are calculated and listed in Appendix C. In order to analyze the effect of using cold exergy of LNG evaporation and cooling the inlet air to the compressor, four engines with different output power $(20-2000 \mathrm{KW})$ are modeled and examined. The operational characteristics and useful variables of the selected engines are shown in Table 1.

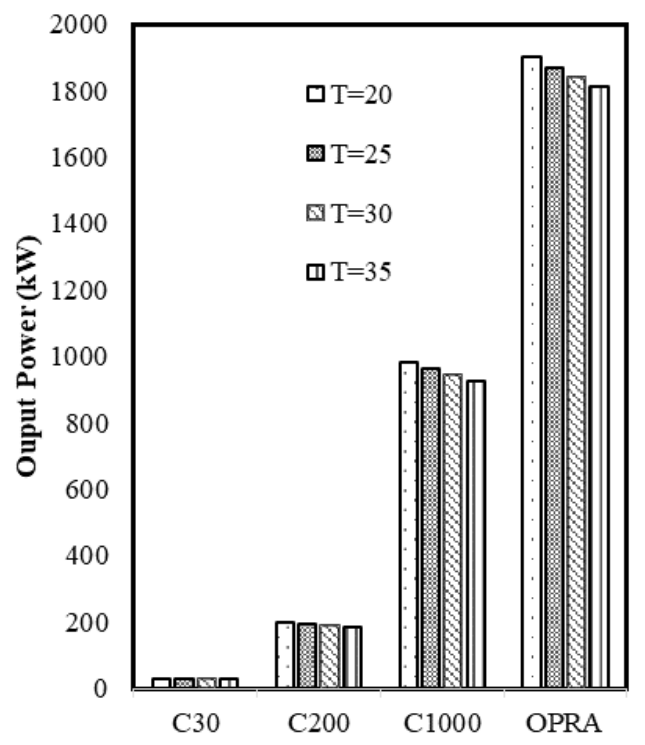

A) methane fuel

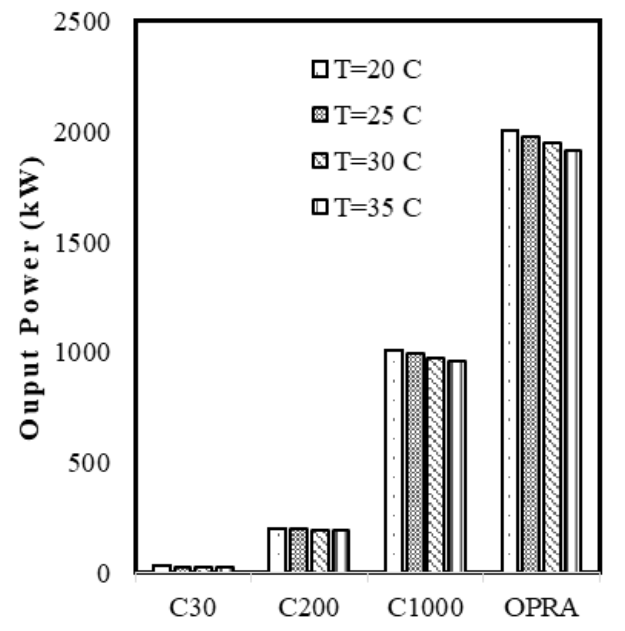

B) LNG fuel

Figure 2. Amount of output power for different motor engines.
The comparison between thermal efficiency and output power for selected gas turbines are shown in Table 2. The results show that using LNG instead of methane in the gas turbine cycle will always be accompanied by increased power and efficiency. This increase in the output power of the cycle is varied from 3 to 5 percent and for power varied from 0.3 to 2.6. Also, the results show that the highest increase in power and efficiency is related to the $2 \mathrm{MW}$ OP16. So this engine is select for further analysis.

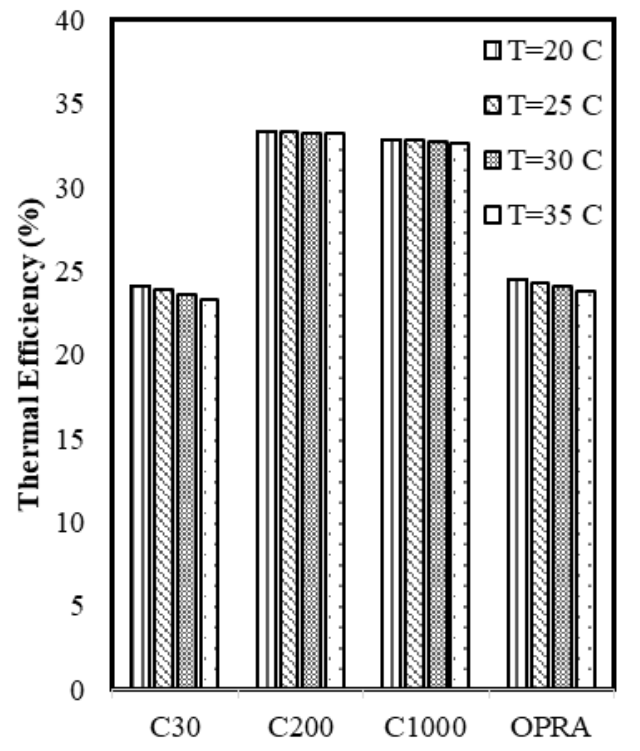

A) methane fuel

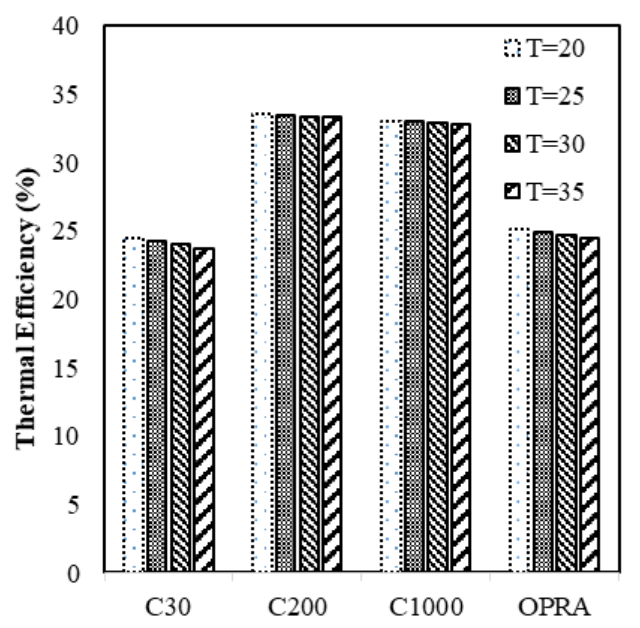

B) LNG fuel

Figure 3. Amount of thermal efficiency for different motor engines. A) methane fuel. B) $L N G$ fuel. 
Comparison between output power and thermal for selected gas turbines with methane and LNG fuel at various ambient temperatures are shown in Figure 2 and Figure 3. Results show that the output power and thermal efficiency are decreased with increase in ambient air temperature. Also, for at all ambient temperature, the OP16 $2 \mathrm{MW}$ gas turbine has the highest output power and efficiency.

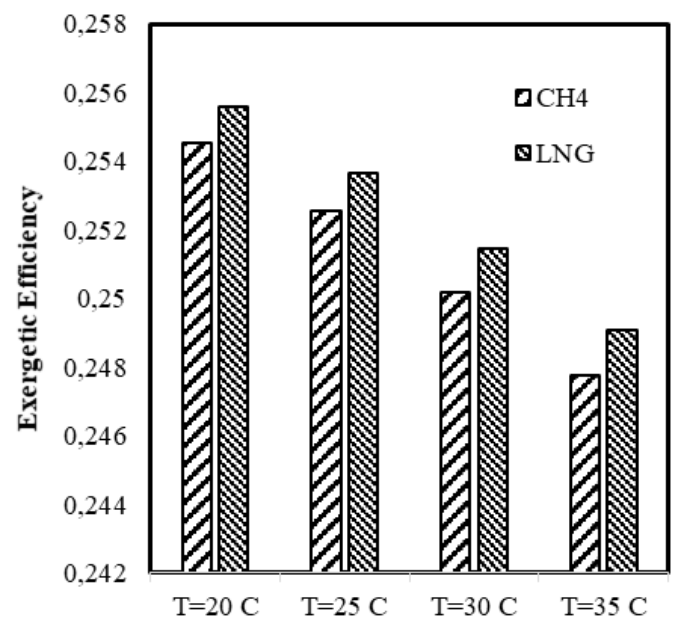

Figure 4. Comparison of exergetic efficiency for gas turbine with LNG and Methane fuel.

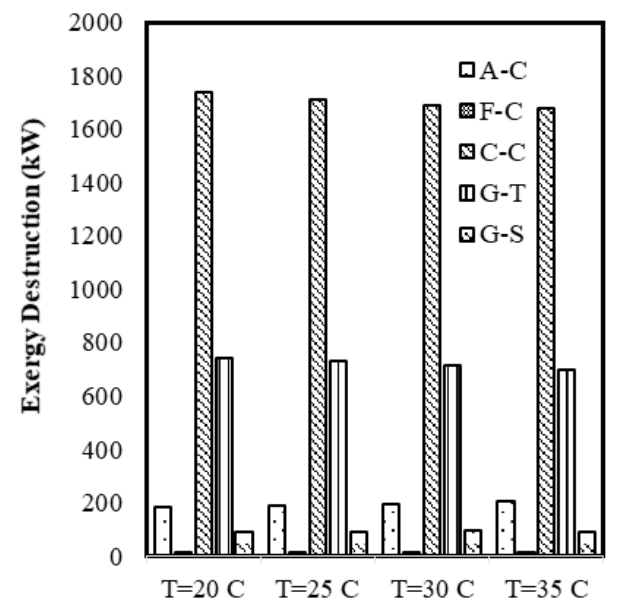

Figure 5. Comparison of the exergy destruction for different equipment for $2 M W$ gas turbine with methane fuel. (A-C: air compressor, F-C: fuel compressor, C-C: combustion chamber, G-T: gas turbine, G-S: stack).
The magnitude of exergetic efficiency at different ambient temperature for a $2 \mathrm{MW}$ engine for two modes of methane and LNG fuel is shown in Figure 4. The results show that, for both cases, the exergetic efficiency is decreased with increase in ambient air temperature. This decrement can be analyzed according to the power reduction in gas turbine cycle due to the increase in ambient temperature. The results show that the exergy efficiencies increase slightly (less than $1 \%$ ) by fuel replacement. This improvement in exergetic efficiency can be analyzed with the cooling of the air entering the compressor in this cycle as well as the reduction of fuel consumption. Although the improvement in exergetic efficiency is low, however, due to the suitable increase in the thermal efficiency (despite the increase of a new heat exchanger to the system), this is a good improvement for the proposed system. The amount of exergy destruction in the different equipment of $2 \mathrm{MW}$ engine cycle is also shown in Figure 5. As the results show, the greatest amount of exergy destruction occurs in the combustion chamber. Therefore, it can be concluded that reducing fuel consumption can have an effective contribution to the rate of destruction of exergy in the combustion chamber and exergy destruction of the gas turbine system.

The exergy cost analysis of $2 \mathrm{MW}$ gas turbine cycle with LNG fuel at different temperatures $\left(15\right.$ and $\left.25^{\circ} \mathrm{C}\right)$ is shown in the following figures and tables. Table 3 shows a summary of fuel exergy, product exergy, irreversibility, the unit exergy cost of the product and its decomposition for each component. In this table, the results show that the combustion chamber and air compressor have the maximum unit exergy cost consumption, respectively. It is shown that these two components have the lowest efficiency in gas turbine cycle. Also, the maximum amount of product exergy cost is related to the stack. This cost shows the waste cost and thus the greatest effect of environmental destruction is due to this equipment. Furthermore, the comparison between Tables 3 and 4 show that, with increasing ambient temperature, cost of unit exergy in the compressor, heat exchanger, fuel compressor which is before the combustion process is increased and in the remaining equipment is decreasing. Also, the results show that the fuel compressor has the lowest unit exergy and thus this component can be defined as an ideal device.

Table 3. The parameters related to the exergy cost in the various equipment for 2-MW gas turbine cycle at Ta=15 ${ }^{\circ} \mathrm{C}$.

\begin{tabular}{|l|c|c|c|c|l|}
\hline Component & $\begin{array}{l}\text { Fuel Exergy } \\
{[\mathrm{kW}]}\end{array}$ & $\begin{array}{l}\text { Product Exergy } \\
{[\mathrm{kW}]}\end{array}$ & $\begin{array}{l}\text { Irreversibility } \\
\mathrm{I}[\mathrm{kW}]\end{array}$ & $\begin{array}{l}\mathrm{k} \\
(\mathrm{kj} / \mathrm{kj})\end{array}$ & $\begin{array}{l}\mathrm{cp} \\
(\mathrm{kj} / \mathrm{kj})\end{array}$ \\
\hline Compressor & 2019.6 & 1816.8 & 202.8 & 1.1116 & 1.1116 \\
\hline Combustion & 9919.5 & 7824.4 & 2095.2 & 1.2678 & 1.3147 \\
\hline Gas Turbine & 7824.4 & 7081.5 & 742.9 & 1.1049 & 2.4739 \\
\hline Heat Exchanger & 8200.5 & 8041.6 & 158.9 & 1.0198 & 1.0198 \\
\hline Fuel Compressor & 8108.1 & 8102.7 & 5.4 & 1.0007 & 1.0203 \\
\hline Stack & 2923.5 & 2848.4 & 75.0 & 1.0263 & 2.5391 \\
\hline
\end{tabular}


Table 4. The parameters related to the exergy cost in the various equipment for $2-\mathrm{MW}$ gas turbine cycle at $\mathrm{Ta}=25^{\circ} \mathrm{C}$.

\begin{tabular}{|l|c|c|c|c|l|}
\hline Component & $\begin{array}{l}\text { Fuel } \\
\text { Exergy }[\mathrm{kW}]\end{array}$ & $\begin{array}{l}\text { Product } \\
\text { Exergy }[\mathrm{kW}]\end{array}$ & $\begin{array}{l}\text { Irreversibility } \\
\mathrm{I}[\mathrm{kW}]\end{array}$ & $\begin{array}{l}\mathrm{k} \\
(\mathrm{kj} / \mathrm{kj})\end{array}$ & $\begin{array}{l}\mathrm{cp} \\
(\mathrm{kj} / \mathrm{kj})\end{array}$ \\
\hline Compressor & 2098.6 & 1884.2 & 214.4 & 1.1138 & 1.1138 \\
\hline Combustion & 9843.5 & 7822.5 & 2021.0 & 1.2584 & 1.3067 \\
\hline Gas Turbine & 7822.5 & 7092.0 & 730.5 & 1.1030 & 2.4513 \\
\hline Heat Exchanger & 8055.6 & 7897.6 & 158.0 & 1.0200 & 1.0200 \\
\hline Fuel Compressor & 7965.2 & 7959.3 & 5.9 & 1.0007 & 1.0206 \\
\hline Stack & 2922.0 & 2861.6 & 60.4 & 1.0211 & 2.5030 \\
\hline
\end{tabular}

Stack

Fuel Compressor 目

Heat Exchanger 目

Gas Turbine

Combustion Chamber

Compressor
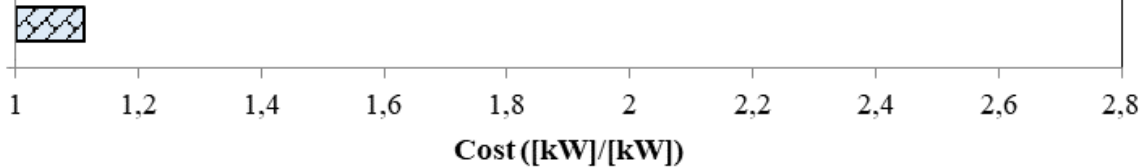

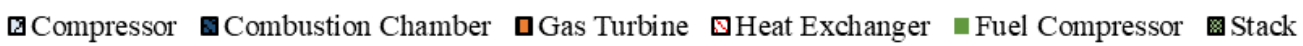

Figure 6. Exergy cost ratio in the different equipment of 2-MW gas turbine cycle at the temperature of $15^{\circ} \mathrm{C}$.

Stack

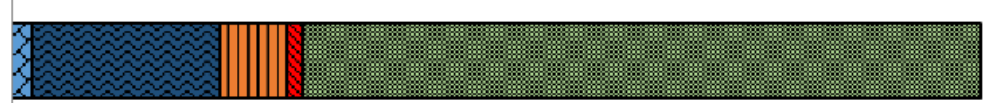

Fuel Compressor

Heat Exchanger

Gas Turbine

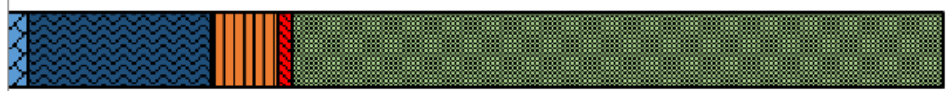

Combustion Chamber

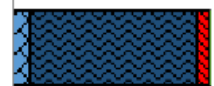

Compressor

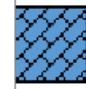

\begin{tabular}{lllllllll}
\hline 1 & 1,2 & 1,4 & 1,6 & 1,8 & 2 & 2,2 & 2,4 & 2,6
\end{tabular}

Environment

๑Compressor

a Combustion Chamber $\mathbf{\square}$ Gas Turbine

由 Heat Exchanger

- Fuel Compressor

. Stack

Figure 7. Exergy cost ratio in the different equipment of $2 \mathrm{MW}$ gas turbine cycle at the temperature of $25^{\circ} \mathrm{C}$ 
The graph of the unit exergy cost of the products of different component in the gas turbine cycle is shown in Figure 6 and 7. In these figures, the effect of the irreversibilities taking place in the production process and the residues are considered. Figures show that highest influence of the cost is stack and combustion chamber. In these devices have major effects on the unit cost of all components. But LNG heat exchanger only affects its own cost. Compression of Figure 6 and 7 show that increasing in ambient air temperature does not affect unit exergy cost of components.

\section{Conclusions}

In this paper, the effect of using LNG fuel instead of methane on thermal efficiency, exergetic parameters and environmental effect in small gas turbines is considered. The results if the first and second law of thermodynamics show that the power and efficiency of gas turbine engines in the range of micro and mini power is improved using the cold exergy of LNG. But the highest improvement has been seen in a 2-MW gas turbine engine. The results of exergy analysis show that, in the gas turbine with LNG fuel, the exergetic efficiency is higher than gas turbine with methane fuel. Results of exergy cost analysis show that the combustion chamber and stack have the maximum unit exergy cost in gas turbine cycle and these components have major effects on the unit cost of all components. Thus improvement in these components can decrease the exergy destruction and environmental disadvantage.

\begin{tabular}{|c|c|}
\hline Nomenclature & \\
\hline Efficiency & $\eta$ \\
\hline Enthalpy & $\mathrm{h}$ \\
\hline Entropy & $\mathrm{s}$ \\
\hline Exergy & $\mathrm{e}$ \\
\hline Exergy Cost & $c$ \\
\hline Exergy Destruction & $\dot{E}$ \\
\hline Gas Constant & $\bar{R}$ \\
\hline Heat & $\dot{Q}$ \\
\hline Mass Flow Rate & $\dot{\mathrm{m}}$ \\
\hline Molar Fraction & $x_{k}$ \\
\hline Output Power & $\dot{W}$ \\
\hline Pressure Drop & $\Delta P$ \\
\hline Pressure & $\mathrm{P}$ \\
\hline Specific Heat & $\mathrm{C}_{\mathrm{p}}$ \\
\hline Temperature & $\mathrm{T}$ \\
\hline Thermal Fuel Value & LHV \\
\hline Subscripts & \\
\hline Potential & $\mathrm{p}$ \\
\hline Kinetic & $\mathrm{k}$ \\
\hline ISO & 0 \\
\hline Combustion Chamber & $\mathrm{cc}$ \\
\hline Chemical & $\mathrm{ch}$ \\
\hline Destruction & $\mathrm{D}$ \\
\hline Physical & $\mathrm{ph}$ \\
\hline
\end{tabular}

\section{References}

[1] Pegg R. Foster, Method and apparatus for increasing power output and/or thermal efficiency of a gas turbine power plant, (1971) US3796045A.

[2] B. Mohanty, G .PalosoJr, Enhancing gas turbine performance by intake air cooling using an absorption chiller, Heat Recovery Systems and CHP, 15 (1) (1995) 41-50.

[3] M. De Lucia, C. Lanfranchi, V. Boggio, Benefits of Compressor Inlet Air Cooling for Gas Turbine Cogeneration Plants, International Gas Turbine and Aeroengine Congress and Exposition, (1995) doi:10.1115/95-GT-311.

[4] Y.S.H. Najjar, Enhancement of performance of gas turbine engines by inlet air cooling and cogeneration system, Applied Thermal Engineering, 16 (2) (1996) 163-173.

[5] J. Palsson, A. Selimovic, L. Sjunnesson, Combined solid oxide fuel cell and gas turbine systems for efficient power and heat generation, Journal of Power Sources , 86 (1-2) (2000) 442-448.

[6] A.M. Bassily, Effects of evaporative inlet and aftercooling on the recuperated gas turbine cycle, Applied Thermal Engineering, 21 (18) (2001) 1875-1890.

[7] F.J. Wang, J.S. Chiou, Integration of steam injection and inlet air cooling for a gas turbine generation system, Energy Conversion and Management, 45 (1) (2004) 15-26.

[8] M.M. Alhazmya, Y.S.H .Najjar, Augmentation of gas turbine performance using air coolers, Applied Thermal Engineering 24 ( 2-3) (2004) 415-429.

[9] C. Yang, Z. Yanga, R. Cai, Analytical method for evaluation of gas turbine inlet air cooling in combined cycle power plant, Applied Energy, 86 (6) (2009) 848-856.

[10] M. Farzaneh-Gord, M. Deymi-Dashtebayaz, Effect of various inlet air cooling methods on gas turbine performance, Energy, 36 (2) (2011) 11961205.

[11] D.Olivenza-León, A. Medina, A. Calvo Hernández, Thermodynamic modeling of a hybrid solar gas-turbine power plant, Energy Conversion and Management, 93 (2015) 435-447.

[12] Yousef N.Dabwan, Esmail M.A.Mokheimer, Optimal integration of linear Fresnel reflector with gas turbine cogeneration power plant, Energy Conversion and Management, 148 (2017) 830-843.

[13] Ashkan. Entezari, Ali. Manizadeh,Rouhollah. Ahmadi, Energetical, exergetical and economical optimization analysis of combined power generation system of gas turbine and Stirling engine, Energy Conversion and Management, 159 (2018) 189-203.

[14] M.J.Santos, C. Miguel-Barbero, , R.P. Merchán, A. Medina, A. Calvo Hernández, Roads to improve the performance of hybrid thermosolar gas turbine power plants: Working fluids and multi-stage configurations, Energy Conversion and Management, 165 (2018) 578-592.

[15] H. Sayyaadi, M. Babaelahi. Exergetic Optimization of a Refrigeration Cycle for ReLiquefaction of LNG Boil-Off Gas. Int. J. of 
Thermodynamics, 13 (4) (2010) 127-133 ISSN 13019724.

[16] Valero, S. Usón, C. Torres, W. Stanek, Chapter Book: Theory of Exergy Cost and Thermo-Ecological Cost, Thermodynamics for Sustainable Management of Natural Resources, Springer (2017).

\section{Appendix A}

The heat exchanger (LNG vaporizer): in LNG vaporizer the inlet air into the compressor is dried by the cold exergy of LNG evaporation and its temperature is reduced.

$$
\begin{aligned}
& \sum(\dot{\mathrm{m}} h)_{\text {in }}=H_{f g}+\sum(\dot{m} h)_{\text {out }} \\
& \dot{m}_{\text {air }} h_{1}+\dot{m}_{\text {fuel }} h_{8} \\
& =H_{f g}+\dot{m}_{\text {air }} h_{2}+\dot{m}_{\text {fuel }} h_{9}
\end{aligned}
$$

Air compressor: The compressor with $86 \%$ isentropic efficiency increases the inlet air pressure. The required compressor work is part of the output power of the gas turbine.

$$
\begin{aligned}
& \eta_{\text {is,comp }}=\frac{h_{3 s}-h_{2}}{h_{3}-h_{2}} \\
& h_{3}=\frac{h_{3 s}-h_{2}}{\eta_{i s, c o m p}}+h_{2} \\
& \dot{W}_{C}=\dot{m}_{\text {air }}\left(h_{3}-h_{2}\right) \\
& h=c_{p, a i r} \Delta T
\end{aligned}
$$

Combustion chamber: the amount of thermal fuel value (LHV) is equal to $50000 \mathrm{KJ} / \mathrm{Kg}$. The heat dissipation from the combustion chamber is considered $2 \%$ of the combustion heat. It is also assumed that the pressure decreases by $2 \%$ of the input pressure.

$$
\begin{aligned}
& \dot{m}_{a} h_{4}+\dot{m}_{f} L H V=\dot{m}_{g} h_{5}+\dot{Q}_{l, C C} \\
& \dot{Q}_{l, C C}=\dot{m}_{f} L H V\left(1-\eta_{C C}\right) \\
& \dot{m}_{g}=\dot{m}_{a}+\dot{m}_{f} \\
& \mathrm{P}_{5}=P_{4}\left(1-\Delta P_{C C}\right)
\end{aligned}
$$

The heat exchanger (Recuperator): in the recuperator, the exhaust air from the compressor is preheated by exhaust gases of the turbine. This method avoids heat dissipation and increases cycle efficiency.

$$
\begin{aligned}
& \sum(\dot{m} h)_{\text {in }}=\sum(\dot{m} h)_{\text {out }} \\
& \dot{m}_{\text {air }} h_{3}+\dot{m}_{g} h_{6}=\dot{m}_{\text {air }} h_{4}+\dot{m}_{g} h_{7}
\end{aligned}
$$

Gas turbine: power is made by combining the exhaust gases from the combustion chamber to the gas turbine's blades with an isentropic efficiency of $90 \%$,

$$
\begin{aligned}
& \eta_{\text {is }, \text { Tur }}=\frac{h_{6}-h_{5}}{h_{6 \mathrm{~s}}-h_{5}} \\
& h_{6}=\eta_{\text {is,Tur }}\left(h_{6 \mathrm{~s}}-h_{5}\right)+h_{5} \\
& \dot{W}_{\text {Tur }}=\dot{m}_{g}\left(h_{6}-h_{5}\right) \\
& h=c_{\text {p,air }} \Delta T
\end{aligned}
$$

Output profit: the output profit of a cycle is equal to the difference between the turbine production work andthe compressor's work.

$$
\dot{W}_{\text {net }}=\dot{W}_{\text {Tur }}-\dot{W}_{C}
$$

\section{Appendix B}

The heat exchanger (LNG vaporizer): in the heat exchanger, the exergy values of work are equal to zero. The heat dissipation from heat exchanger is considered a part of the external irreversibility, and is integrated in the exergy destruction term, and the term of exergy destruction in equations includes the amount of thermal exergy loss.

$\sum_{\text {in }} \dot{m}_{\text {in }} e_{\text {in }}-\sum_{\text {out }} \dot{m}_{\text {out }} e_{\text {out }}=\dot{E}_{D}$

$\left(\dot{m}_{1} e_{1}+\dot{m}_{8} e_{8}\right)-\left(\dot{m}_{2} e_{2}+\dot{m}_{9} e_{9}\right)=\dot{E}_{D}$

$e_{1}=e_{p h}$

$e_{2}=e_{p h}$

$e_{8}=e_{p h}+e_{c h}$

$e_{9}=e_{p h}+e_{c h}$

Air compressor: assuming that, it is adiabatic, the air compressor has no dissipation, so the exergy temperature value is zero and the exergy analysis is defined as follows.

$$
\begin{aligned}
& -\dot{W}+\sum_{\text {in }} \dot{m}_{\text {in }} e_{\text {in }}-\sum_{\text {out }} \dot{m}_{\text {out }} e_{\text {out }}=\dot{E}_{D} \\
& \dot{W}+\dot{m}_{2} e_{2}-\dot{m}_{3} e_{3}=\dot{E}_{D} \\
& e_{3}=e_{p h}
\end{aligned}
$$

The heat exchanger (recuperator): in the recuperator, similar to the heat exchanger (LNG vaporizer), the heat exergy and work are equal to zero, so the exergy analysis is obtained as follows. 


$$
\begin{aligned}
& \left(\dot{m}_{3} e_{3}+\dot{m}_{6} e_{6}\right)-\left(\dot{m}_{4} e_{4}+\dot{m}_{7} e_{7}\right)=\dot{E}_{D} \\
& e_{4}=e_{p h} \\
& e_{6}=e_{p h}+e_{c h} \\
& e_{7}=e_{p h}+e_{c h}
\end{aligned}
$$

Combustion chamber: by removing the heat and work exergy from Eq. 18, the following equation is obtained for the combustion chamber.

$$
\begin{aligned}
& \sum_{\text {in }} \dot{m}_{\text {in }} e_{\text {in }}-\sum_{\text {out }} \dot{m}_{\text {out }} e_{\text {out }}=\dot{E}_{D} \\
& \left(\dot{m}_{4} e_{4}+\dot{m}_{10} e_{10}\right)-\left(\dot{m}_{5} e_{5}\right)=\dot{E}_{D} \\
& e_{10}=e_{p h}+e_{c h} \\
& e_{5}=e_{p h}+e_{c h}
\end{aligned}
$$

Gas turbine: by removing heat exergy from Eq. 18, the exergy destruction of the gas turbine is obtained from the equation.

$$
\begin{aligned}
& -\dot{W}+\sum_{\text {in }} \dot{m}_{\text {in }} e_{\text {in }}-\sum_{\text {out }} \dot{m}_{\text {out }} e_{o u t}=\dot{E}_{D} \\
& -\dot{W}+\dot{m}_{5} e_{5}-\dot{m}_{6} e_{6}=\dot{E}_{D}
\end{aligned}
$$

Exergetic efficiency is one of the important parameters for irreversibility evaluation that defined based on fuel-product definition as bellow:

$$
\varepsilon=\text { product } / \text { fuel }
$$

\section{Appendix C}

Table C.1: The calculated thermodynamic parameters (Capston C30).

\begin{tabular}{|c|c|c|c|c|c|c|}
\hline & \multicolumn{2}{|c|}{ Mass flow (kg/s) } & \multicolumn{2}{c|}{ Temperature (C) } & \multicolumn{2}{c|}{ Pressure (bar) } \\
\hline $\begin{array}{c}\text { 古 } \\
\text { I }\end{array}$ & CH4 & LNG & CH4 & LNG & CH4 & LNG \\
\hline 1 & 0.307 & 0.307 & 15 & 15 & 1.013 & 1.013 \\
\hline 2 & 0.307 & 0.307 & 196.9 & 8.312 & 4.052 & 0.974 \\
\hline 3 & 0.3077 & 0.307 & 454.6 & 186.2 & 3.896 & 3.897 \\
\hline 4 & 0.31 & 0.31 & 776.7 & 444.7 & 3.82 & 3.747 \\
\hline 5 & 0.31 & 0.31 & 524.9 & 776.7 & 1.005 & 3.674 \\
\hline 6 & 0.31 & 0.31 & 275 & 525 & 0.985 & 0.966 \\
\hline 7 & 0.0023 & 0.31 & 143.2 & 275 & 5.455 & 0.947 \\
\hline 8 & --- & 0.002 & --- & -162 & --- & 1.033 \\
\hline 9 & --- & 0.002 & --- & 9.995 & --- & 1.013 \\
\hline 10 & --- & 0.002 & --- & 116 & --- & 5.246 \\
\hline
\end{tabular}

Table C.2: The Exergy destruction of $\mathrm{CH} 4$ in the various equipment for 2-MW gas turbine cycle at $\mathrm{Ta}=15^{\circ} \mathrm{C}$

\begin{tabular}{|l|l|}
\hline Component & Exergy destruction $(\mathrm{KW})$ \\
\hline Compressor & 179.04 \\
\hline Fuel Compressor & 11.98266 \\
\hline Combustion & 1767.3816 \\
\hline Gas Turbine & 748.31613 \\
\hline Stack & 91.9438 \\
\hline
\end{tabular}

Table C.3. The Exergy destruction of $L N G$ in the various equipment for 2-MW gas turbine cycle at $\mathrm{Ta}=15^{\circ} \mathrm{C}$

\begin{tabular}{|l|l|}
\hline Component & Exergy destruction $(\mathrm{KW})$ \\
\hline LNG Vap & 185.5871 \\
\hline Compressor & 176.089 \\
\hline Fuel Compressor & 5.3863 \\
\hline Combustion & 2095.1817 \\
\hline Gas Turbine & 742.8945 \\
\hline Stack & 65.0481 \\
\hline
\end{tabular}

